Article

\title{
Rural Winery Resiliency and Sustainability through the COVID-19 Pandemic
}

\author{
Kynda R. Curtis ${ }^{1}$ and Susan L. Slocum ${ }^{2, *(D)}$ \\ 1 Department of Applied Economics, 4835 Old Main Hill, Utah State University, Logan, UT 84322, USA; \\ kynda.curtis@usu.edu \\ 2 Department of Tourism and Events Management, Fairfax Campus, George Mason University, Krug Hall \\ 213A, 4400 University Dr., MS 4D2, Fairfax, VA 22030, USA \\ * Correspondence: sslocum@gmu.edu
}

Citation: Curtis, K.R.; Slocum, S.L. Rural Winery Resiliency and Sustainability through the COVID-19 Pandemic. Sustainability 2021, 13, 10483. https://doi.org/10.3390/ su131810483

Academic Editors: Elisabeth

Kastenholz, Bernard Lane and Maria João Carneiro

Received: 16 August 2021

Accepted: 18 September 2021

Published: 21 September 2021

Publisher's Note: MDPI stays neutral with regard to jurisdictional claims in published maps and institutional affiliations.

Copyright: (c) 2021 by the authors. Licensee MDPI, Basel, Switzerland. This article is an open access article distributed under the terms and conditions of the Creative Commons Attribution (CC BY) license (https:// creativecommons.org/licenses/by/ $4.0 /)$.

\begin{abstract}
The COVID-19 pandemic has adversely affected the tourism industry worldwide, including the wine industry in the western U.S. due to mandated winery and tasting room closures, followed by restrictions on capacity and food- and drink-handling once wineries reopened. In California, tasting rooms were fully closed from mid-March to mid-May 2020 and could not have visitors indoors through to October 2020. Hence, this study examines the resiliency of wineries in minor California wine regions, including the challenges faced during the pandemic, strategies used to sustain their business, and the attributes of their operation which contributed to success. Data were collected through structured in-person interviews with five wineries in minor California wine regions, specifically Russian River Valley and Sierra Foothills. The four themes which emerged include: lifestyle business; market differentiation; direct marketing; and the effects of COVID-19. These wineries are primarily family-owned, which gives them the ability to control costs and make decisions rapidly. They did not have a large workforce or multiple layers of management, allowing them to pivot quickly to adjust to the regulatory environment. This study on rural winery resilience during the COVID-19 pandemic will assist rural tourism operations in dealing with social and economic shocks in the future.
\end{abstract}

Keywords: winery; rural tourism; resiliency; economic shocks

\section{Introduction}

On 11 March 2020, the World Health Organization (WHO) declared COVID-19 a global pandemic, its Director-General stating, "This is not just a public health crisis, it is a crisis that will touch every sector" [1], np. While the pandemic did impact multiple sectors of the economy, the travel and leisure industries were especially hard-hit due to outright closures, capacity restrictions, and new safety-based regulations.

To stop the spread of COVID-19 in the United States, most non-essential businesses and government offices were closed from one and a half to three months, depending on the state, starting in mid-March 2020. As a result, consumer spending on restaurants and hotels fell by $66.5 \%$ between 12 March 2020 and 1 April 2020 (see Figure 1). Consumer spending in this sector rebounded but was still $22.4 \%$ below January 2020 levels as of January 2021 [2]. It was not until 1 April 2021, that spending at hotels and restaurants increased above January 2020 levels.

In rural areas, the tourism industry was especially impacted [3] due to closures and travel restrictions. In California, for example, food, drink, and other tourism providers were fully closed from mid-March to mid-May 2020. Once open, restaurants, wineries, breweries, and so forth could not have visitors indoors until October 2020. Shelter-inplace and lockdown orders in major counties in the San Francisco Bay region brought non-essential travel, including tourism to nearby California wine regions, to a halt. As 
many rural areas were already lagging behind urban areas prior to the pandemic $[4,5]$, the loss of tourism revenue may have lasting implications.

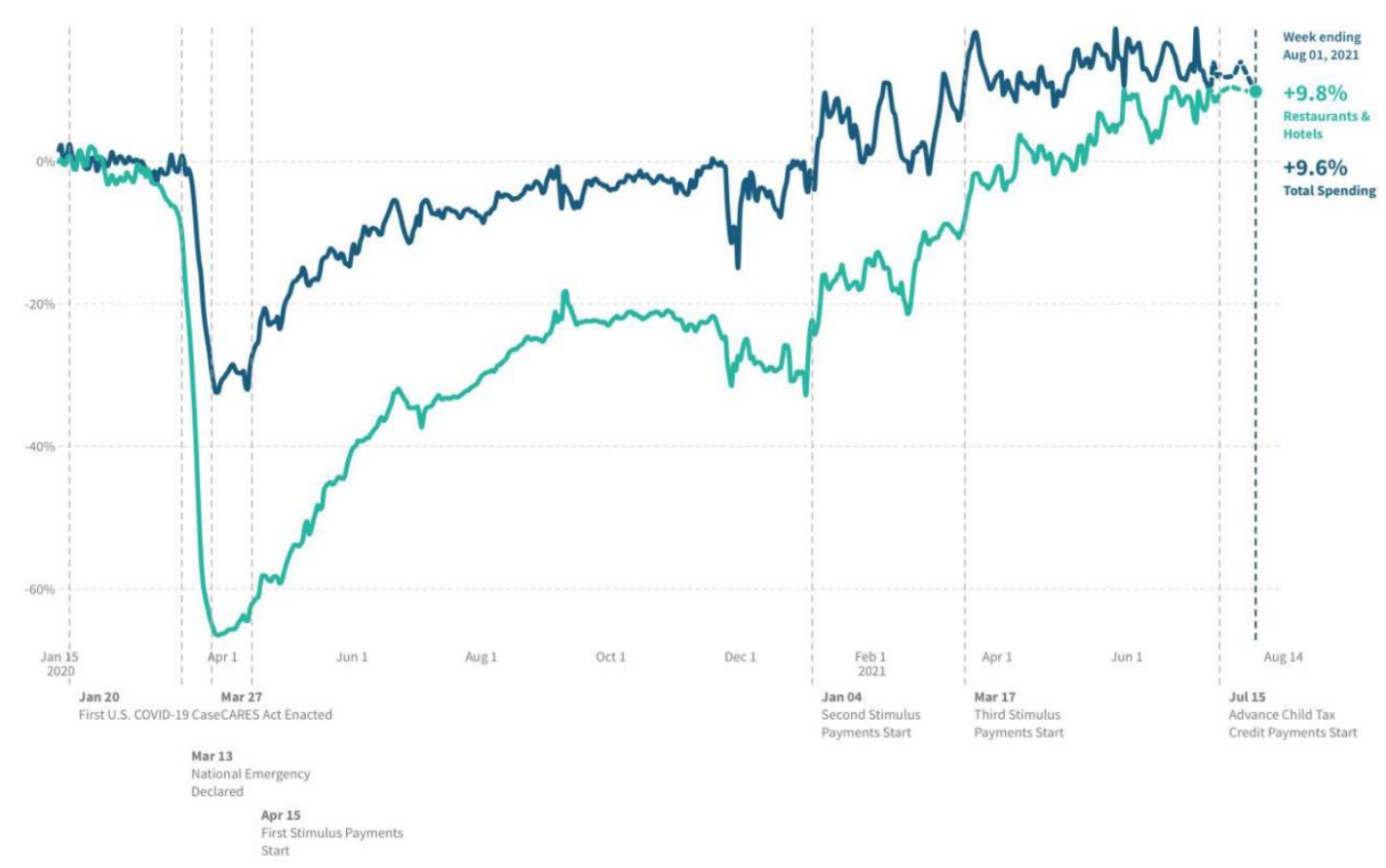

Figure 1. Total consumer spending and spending on restaurants and hotels, United States, January 2020 to August 2021. Source: Opportunity Insights [2].

California is the leading wine producer in the United States and the fourth largest wine producer worldwide. California generates $80 \%$ of all domestically produced wine in the United States. In 2021, there were 4200 bonded wineries and 5900 wine grape growers in California. The 2021 retail value of California wine sales was $\$ 43.6$ billion, creating $\$ 3.24$ billion in farmgate value for wine grape growers [6]. The wine industry is important to the California economy ( $\$ 56.7$ billion in economic impact and 325,000 jobs annually) and rural tourism is essential to California's wine regions, which hosts 23.6 million visitors who spend $\$ 7.2$ billion annually [6].

While wine regions, such as Napa Valley, Sonoma County, Paso Robles, and Santa Maria Valley are well-known tourism destinations, there are many other important wine regions in California, such as the Sierra Foothills, Lodi, Anderson Valley, Russian River Valley, and so forth. These minor California wine regions bring their own flair to the rural tourism offering. Minor wine region wineries are small family-owned firms employing multiple familial generations [6]. Wineries in the Sierra Foothills region are at a higher elevation than those in Napa and Sonoma, and thus offer different varietals, such as those from Italy and Hungary. The higher elevation provides lower temperatures and increased ventilation in vineyards, which slows wine grape ripening and preserves acidity [7]. It is difficult to ripen varieties like Cabernet Sauvignon or Petit Verdot at high elevations, so earlier-ripening grapes, such as Malbec and Pinot Noir, are grown. The Fort Ross-Seaview American Viticultural Area (AVA) in the Russian River Valley region is also at a higher elevation (900 to 2000 feet). In this area, the grapes are grown near the Pacific Ocean, which brings in cool ocean air, and thus high-quality Pinot Noirs and Chardonnays are produced [7].

In addition to the COVID-19 pandemic, California's wine regions have been hit hard by drought and wildfire in recent years. The 2020 fire season is estimated to have cost California wine grape-growers 3.55 million tons in lost grapes and reduced the North Coast (Napa, Sonoma, etc.) harvest by $30 \%$ [8]. Not only did the fires damage vineyards 
and winery buildings, but the smoke also marred grapes in production. When grapes are exposed to smoke, the resulting wines may be smoke-tainted, meaning they contain undesirable sensory characteristics, such as ashy, smoky, or bunt flavors [9].

Due to the large impact of the COVID-19 pandemic on rural tourism and the importance of the wine industry in California, this study examines the resiliency of wineries in minor California wine regions, specifically the Russian River Valley and Sierra Foothills, during the COVID-19 pandemic. This study contributes to the scant literature on resiliency in the tourism industry by incorporating the theory on resilient business models from the business literature. Hence, strategies the wineries employed to sustain their business and the attributes of their operation which contributed to their success are explained. This study on rural winery resilience during the COVID-19 pandemic will assist rural tourism operations in preparing for and increasing their ability to withstand future economic shocks.

\section{Literature Review}

The COVID-19 pandemic created an economic crisis or shock, defined as an unexpected change in the economy. Previous literature on firm-level resiliency post-economic shock provides a framework to explore the resilience of wineries in minor California wine regions. Firm or enterprise resilience is defined as the capacity for an enterprise to survive, adapt, and grow in the face of unexpected or turbulent change [10]. Moreover, resiliency can be the ability of an operation to return to its original state or to a new, improved state after experiencing a disruption, and thus avoid failure or prevent a shift to an undesirable condition [11]. Slocum and Kline state, "While resilience can be seen as a strategy to facilitate recovery after a traumatic event, it can also be used as a preventative measure to avoid poor outcomes. Therefore, resilience is not about controlling conditions, but developing the ability to respond to change" [12], p. 404.

The literature on resiliency in tourism is sparse, but there are many studies on resiliency in small businesses and family-owned firms to draw from. The literature cites a wide variety of factors that contribute to firm or organizational resiliency post-crisis. For example, the elements that make an organization resilient to a crisis are the presence of social capital, training and education, adaptability, knowledge, creativity, receptiveness, and flexibility [13]. Slocum and Kline [12] declared that resilience should be viewed as a positive adaptive response to adversity where actors can draw on natural, human, cultural, social, financial, built, and political capital to negotiate change [13]. Finally, Seville, Van Opstal, and Vargo [14] provided seven principles of a resilient organization, including adaptive capacity, leaders people want to follow, learning organizations, building social capital, operational excellence, resilience as a team sport, and seeing the opportunities. A few common factors emerge from the literature and provide a template for the organizational factors which lead to firm resiliency or improve a firm's likelihood of survival during and after an economic crisis or shock. Each is discussed below.

\subsection{Simple Organizational Structure-Short Management Span}

The first factor is a simple organizational structure or short management span. The management span is the number of underlings that a particular supervisor leads. In a study on firm-based resiliency after economic shock, Sabatino [15] found that resilient enterprises employ a simplified structure, with an average of 8 to 10 people between top management and front-line personnel (i.e., a short management span). Christopher and Towill [16] outlined the need to integrate leanness and agility to create a resilient manufacturing strategy. A correctly implemented strategy can increase capacity, encourage responsiveness, and reduce costs. Simplified organizations have greater control over their cost structure [15].

Additionally, small family firms often have structures that enable more effective financial management [17]. A family firm's capacity to access human, social, and financial resources is positively related to its survival $[18,19]$. Superior financial management provides firms with the ability to better absorb economic shocks and take advantage of new 
opportunities in the unfolding economic environment [20]. Specific to tourism operations, reliance on large-scale tourism businesses negatively impacted the recovery of Khao Lak, Thailand after the 2004 Tsunami, an exogenous shock to its economy [21].

\subsection{Rapid Decision-Making}

In times of crisis, it is no surprise that firms need to rapidly pivot their operations. Sabatino [15] found that enterprises that make decisions rapidly have a high resilience rate. The author notes, however, that despite the lack of time to completely process new information, firms that follow simple rules and make quick decisions are more competitive in the long-term [22].

A study on the role of family ownership on resilience in rural hospitality firms [23] illustrates that rural family-run hotels thrive and are considered resilient, as they can take situation-specific, vigorous, transformative actions at times of unexpected change. Similarly, when addressing manufacturing firm resilience, lean, agile, or responsive firms with strong business functions in marketing, communication, and product innovation are more competitive and resilient [24,25]. Both Thomas et al. [25] and Engeset [23] point out that small non-complex firms are often able to make decisions more rapidly. This adds to the merits of the simple organization structures discussed above.

For all firms, even if they may be larger in management span, management must create clear management processes to deal with shocks and delegate decision-making authority to those on the front lines [25]. This allows those likely to detect changes early to respond quickly and proactively.

\subsection{Focus on Main (Core) Competencies}

The literature on business organization states that the most resilient enterprises are those that simplify their business structure and focus on their main competencies, which are the "core competencies" or "experience areas" at which an enterprise excels $[15,26,27]$. Similarly, in economics, regions or firms are imparted to focus on those goods or services in which they have a comparative advantage, meaning products they can produce more efficiently or at a lower opportunity cost than others. Thus, while some amount of diversification may enable firms to survive unexpected economic changes [28], the theory does not recommend that firms attempt to serve all markets or consumers.

The literature goes as far as to say that firms should make adaptive capacity a core competency [25]. Adaptive capacity is built from a firm's risk intelligence, flexibility, and readiness for change, and "If change is the new normal, then adaptive capacity is the requisite for dealing with this reality" (p. 6). As elements of adaptive capacity include creativity and flexibility, more discussion on this follows.

\subsection{Creativity and Flexibility}

The resilience of a firm is as successful as its ability to react to economic shocks with creativity and flexibility [29]. Khan, Christopher, and Creazza [30] claim that to assure resiliency and sustainability, firms need to become more impervious to disruptions and to quickly return to the previous or improved state after a disturbance has affected performance; therefore, manufacturing firms need to become more flexible and innovative in the development of their products and processes. Christopher [31] describes agility as a firmwide capability that informs organizational structure, information systems, logistics, and mindsets. The author identifies the key characteristic of an agile organization as flexibility.

Encouraging creativity within an organization is often contrary to traditional management styles. However, resilient organizations more often encourage continuous experimentation and innovation, not just in product and service design, but also in business processes and strategies [25]. Creativity and innovation are often addressed through technology adoption and the adoption of a culture of learning within the organization [28]. An organization that emphasizes learning can evolve with changing environments and see more value in listening than talking. Hence, "Resilient organizations make knowledge-sharing 
and knowledge management available on an ongoing basis" [25], p. 9. One study on the resilience of communities to recover economically and socially after a natural disaster found that one primary dimension of resilience included community leaders who generated novel ideas to address change and learned to combine resources in creative ways [12].

\subsection{Customer-Centered}

Customer-centric is an organizational strategy in which a firm's future actions in marketing, product developing, and operations are built according to customer priorities [32]. Sabatino [15] states that the most resilient enterprises are those that in times of crisis or major change, focus on customers and their needs. The results of Thomas et al. [25] show that, for the manufacturing companies in their study, removing waste from production processes, as well as making the company more responsive and agile to customer needs, was key to continued resiliency [33]. Other studies conducted on the complexity of customer needs, customer-centricity, innovativeness, service differentiation, and business performance confirm the authors' findings [34].

\subsection{Developed Social Networks}

Social capital theory argues that relational networks constitute a valuable resource for a firm by facilitating economic activity through information and resource sharing, collaboration, and the discovery of new methods that provide the firm with a competitive advantage [35-37]. Social capital comes from lasting personal networks of employees who establish particularly close ties to stakeholders, which makes them excellent business partners $[17,38]$.

In the literature, there are numerous references to the value of social capital, the networks and resources available through connections with others. Social capital, next to financial capital, has been touted as essential to a successful or sustainable business [25]. In a study by Mzid, Khachlouf, and Soparnot [17], the social capital of family firms made up of both local and international contacts contributed the most to a firm's ability to cope with external disturbances. Additionally, Maroudas, Kyriakaki, and Gouvis [39] state that, "The cohesion and welfare of the local community and the existence of networks between business units of the community, nongovernmental organizations and research centers are essential for endogenous and sustainable tourism development" (p. 17).

\section{Materials and Methods}

Qualitative data were collected through structured in-person interviews conducted with five wineries in minor California wine regions, specifically the Russian River Valley and Nevada County in the Sierra Foothills. These two regions were selected due to their close proximity to the San Francisco Bay market, their close proximity to each other to better enable data collection, and their unique growing conditions which differed from the more popular California wine destinations. Initial winery subjects were identified through regional destination marketing organizations and contacted via phone and email to schedule interviews. Once interviews commenced, snowball sampling was added, in which one interviewee would suggest another interview site [40]. The research team collaboratively developed the interview schedule, deriving the interview questions from the literature on business resiliency [12,13,25] as discussed in the previous section. All questions were open-ended and fell into four primary areas: (1) Winery business details and structure; (2) product offerings and marketing methods; (3) local resources and networks; and (4) COVID-19-related challenges, adjustments, and local COVID-19 restrictions.

Special attention was paid to pre-COVID operations, adaptations during COVID regulatory changes, and reflections on business processes by the participant before and during the lockdown and re-opening. All interviews were recorded and later transcribed. The data were combined and then hand-coded into topics by the research team, individually. The research team then discussed each code and resolved discrepancies. These topics were 
then pooled to develop themes, defined as common plots or ideas running through the data [41].

\section{Results}

The four primary themes which emerged from the data include lifestyle business, market differentiation, direct marketing, and the effects of COVID-19. This section provides data relating to pre-COVID business structures and the economic environment during the pandemic. COVID-related resiliency is presented in the Discussion section.

\subsection{Lifestyle Business}

The wineries in this study can be defined as 'small' by the Small Business Act [42] (as amended in 2021). As agricultural entities, they must employ less than 250 people and have maximum receipts of $\$ 750,000$ or less. Wine production at the research sites ranges from 1000 bottles to 2500 bottles of wine annually, and they employ, at most, 10 people. The largest vineyard is 65 acres, but the rest have 12 acres or less in production (see Table 1). Moreover, these wineries are operated as lifestyle businesses. Lifestyle businesses can be defined as entrepreneurial activities begun for non-economic reasons, often accepting "suboptimal profits" ([43], p. 381) in favour of maintaining a personally satisfying way of life. Priority is placed on balancing adequate income with the needs of family and overall quality of life. As Winery 1 states,

"I moved here from Seattle in 2000. I actually moved here specifically to do what I'm doing. I was starting my family, and I wanted to raise my family in a more rural farming environment, like where I grew up. Making money really isn't the attraction".

Winery 4 adds, "If I want to be in the entertainment business, I should probably run a brothel and make the most amount of money. It's about lifestyle and craft. You're not going to be rich with this". These wineries take pride in their craft, and value the quality of life small-scale wineries offer them. The owner of Winery 3 sees her three grandchildren every day.

Table 1. Overview of study winery characteristics.

\begin{tabular}{|c|c|c|c|c|c|c|}
\hline $\begin{array}{l}\text { Winery } \\
\text { Name }\end{array}$ & $\begin{array}{c}\text { Year } \\
\text { Established }\end{array}$ & $\begin{array}{l}\text { Acreage } \\
\text { Planted }\end{array}$ & $\begin{array}{l}\text { Production } \\
\text { (Cases) }\end{array}$ & $\begin{array}{l}\text { Employees (Full } \\
\text { Time Equivalent) }\end{array}$ & Varieties Produced & $\begin{array}{c}\text { In-Town } \\
\text { Tasting Room }\end{array}$ \\
\hline Winery 1 & 2000 & 9.5 & 1800 & 2.5 & $\begin{array}{c}\text { Sauvignon Blanc, Negroamaro, } \\
\text { Sangiovese, Primitivo, } \\
\text { Teroldego, Barbera, Aglianico, } \\
\text { Dolcetto, Nebbiolo }\end{array}$ & No \\
\hline Winery 2 & 2004 & 3.5 & 1000 & 4 & $\begin{array}{l}\text { Rkatsiteli, Pinot Blanc, Pinot } \\
\text { Grigio, Melon de Bourgogne, } \\
\text { Semillon, Chenin Blanc, Orange } \\
\text { Muscat, Sangiovese, Peverella, } \\
\text { Forastera, Barbera, Dolcetto, } \\
\text { Sangiovese, Carmine, Refosco }\end{array}$ & Yes \\
\hline Winery 3 & 1995 & 12 & 2500 & 2 & $\begin{array}{l}\text { Sauvignon Blanc, Zinfandel, } \\
\text { Cabernet Sauvignon, Barbera, } \\
\text { Chardonnay, Cabernet Franc, } \\
\text { Petite Syrah, Riesling, } \\
\text { Fumé Blanc }\end{array}$ & Yes \\
\hline Winery 4 & 2003 & 10 & 2200 & 1 & $\begin{array}{l}\text { Grenache, Petite Syrah, } \\
\text { Primitivo, Syrah, Varázs, Vizir, } \\
\text { Zinfandel, Sauvignon Blanc }\end{array}$ & Yes \\
\hline Winery 5 & 2001 & 64 & 12500 & $\begin{array}{l}10 \text { (not including } \\
\text { vineyard staff) }\end{array}$ & $\begin{array}{l}\text { Pinot Noir, Chardonnay, Shiraz } \\
\text { (Syrah), Sauvignon Blanc, Rose }\end{array}$ & Yes \\
\hline
\end{tabular}


About half the participants in this study started as hobbyists, realising later that wine-making can be an expensive endeavour. For example, Winery 2 states, "I had been interested in drinking wine and decided to grow a small experimental venue. I put up a deer fence around three quarters of an acre and I got 29 different varietals, and we lived there for 13 years strictly as amateurs". Other participants had a strong background in business and took a more strategic approach to their operations. Winery 4 acknowledges,

"This is a business; it's set up as a business to make money. I wanted to use the agricultural tax status, so that the money I put in increases my investment. This (tasting room) was designed for entertainment. I don't watch TV. I don't play golf. I like people, by and large, and enjoy dealing with the public".

One primary intention of lifestyle businesses is to keep them small and manageable [44], often relying on family contributions in the overall business strategy. Winery 3 employs their son, who is a "second-level sommelier and certified wine judge". Spousal partnerships were common, with distinct divisions of labour, such as wine-making, financial management, or tasting room operations. There were generally only two levels of employment, the family manager and the employees, who were generally part-time. Winery 3 further states, "If you have a lot of employees, then that's going to cost you, that's one of the biggest expenses. So, we do a lot of it ourselves". The owner of Winery 4 does all the spraying, approximately $80 \%$ of the pruning, but brings in a crew for harvesting each autumn. This helps reduce operating costs and builds flexibility into the business model [16].

Many owners have used consultants over the years, as they navigated the steep learning curve of grape-growing and wine-making. Others have tried hiring an outside sale team, only to pivot back to direct-to-consumer sales because of the reduced profit margins. Moreover, managed growth has ensured that the wineries have the resources they need to avoid risk. Winery 1 has " ... increased production by around 100 to 150 cases a year. It's a nice slow, gentle, manageable growth". Winery 5 contracted out the management of the vineyard so they could focus on wine production and the visitor experience at the tasting room. Because of the craft nature of these businesses, flexibility in relation to weather (drought, wildfire), supply chains, and increased competition is a necessity within the overall management strategy of these wineries. The narrow span of control allows owners to make decisions quickly and adjust the business model as needed [13].

\subsection{Market Differentiation}

Slocum and Curtis [45] argue that small lifestyle businesses require niche strategies "to distinguish product offerings, develop promotional strategies, and create a unique brand or image in the mind of the consumers" (p. 47). As small, rural wine-producing regions, the wineries in this study attempted to focus on their unique individual competencies to create a comparative advantage for their individual wineries, but struggled to create an identity for the destination as a whole. Winery 2 explains:

"They have about 50 or 60 wineries in Amador County, and almost that number in Eldorado County. And so, when people think of the Sierra foothills, they think of those two counties and their driving distance to our place here. (Visitors) are going to go there instead of here in many cases. It's just better known. We still have not created an identity as a wine destination with the people that are close enough to come during the day and then go home".

Each winery grows unique grapes, with the majority producing wines not found in other areas of California, which helps differentiate them from local competition. For example, Winery 1 specialises in Southern Italian grapes, Winery 2 has "Italian white varieties that you have never heard of", as well as specialty grapes from Hungary, and Winery 4 offers French and German varietals. Winery 5 faces limitations on the climate, as the California coast can be cool and foggy during the summer, resulting in grapes "that encourage the full expression of Pinot Noir and Chardonnay not seen in warmer regions". 
Since these wineries produce small amounts of product, are not motivated by excessive profit, and maintain lifestyle businesses, one strategic competency is the ability to reject or adapt to more traditional distribution strategies, such as working with wholesalers and/or restaurants and employing local harvesting events, side-stepping expensive and unreliable contractors. Winery 1 explains, "My experience over the 20 years of doing this says the best way to not get paid for all your work is to sell wine to a restaurant", and Winery 3 emphasises, "We've had somebody try to wholesale for us, but there wasn't enough profit, because wholesale takes 30\% just to start". Some wineries used to sell in local grocery chains, but the stores discontinued the practice, and only one winery sold their products to restaurants.

Customer relationships form the backbone of their business model, and also support the creativity and flexibility needed to maintain a craft business mindset [2]. Since up to 70 percent of their business is derived from customers within 100 miles (local, Sacramento, and Reno), customers often join volunteer work parties, attend local events, and buy wine through wine clubs and internet sales. Many wineries struggled to find reliable harvesting personnel, so now used volunteers. For example, Winery 1 "throws a big harvest party and we do a big banquet spread, brunch and too much champagne and too much wine. We'll get 50 or 60 people to come out".

\subsection{Direct Marketing}

Customer-centric business models allow for agility in marketing, merchandising, and operations [32]. Customer relationships have allowed for effective direct-to-consumer marketing through social networking, events, volunteer opportunities, and wine club membership, all of which support business success. Winery 3 elucidates, "Thankfully, we have a really nice wine club that keeps us going". All the wineries offer events, as explained by Winery 2. "My wife has a relationship with some of the local artists and sometimes we'll have an event that is exclusively devoted to displaying this person's art and inviting people in". By maintaining tight relationships with customers, the wineries are better able to adapt to changing consumer needs, retain a higher level of profits, and remain flexible as seasonal output varies [27].

The primary mode for sales is through tasting rooms, which allow for intimate relationships to form and for continuous feedback from consumers. It also provides a visitor experience, which builds customer loyalty [46]. Winery 1 reiterates, "Many of the wineries in this region are too remote, or they're on private roads. Seventy-five percent of the roads in Nevada County are private roads. That's why everyone has a tasting room in town. It's easy". Winery 4 claims, "We knew we needed to get away from the winery because we just didn't get enough traffic. The tasting room is my distribution outlet and that's very important". Winery 3 claims that $80 \%$ of their sales are through their tasting room.

While most customers first experience the winery through the tasting room, wine owners often remain in contact with visitors through wine clubs and social media. This, in turn, supports customer loyalty and long-term relationships, resulting in increased social capital [38]. California and Nevada's liberal liquor laws allow for the direct shipment of wine to households, enhancing existing e-commerce practices. Social media is used to announce new wine releases, upcoming events, discount sales, and general happenings at the wineries. Winery 1 expounds,

"There are books out there about what we can and can't do, in terms of getting wine into the hands of consumers. It's a lot easier if you decide you're just going to ignore the book, and you're just going to do what you have to do. I put it out there on social media and my email list. You buy six bottles of wine, I will deliver it to your door or I will ship it to you for free".

For visitors passing through the region, pre-orders and onsite pickup of wines is easily accommodated. It appears the goal is to provide easy access to wine while still maintain a personal connection to the consumer, which in turn maintains flexibility in relating to customer needs. 


\subsection{The Effects of COVID-19}

Participants were asked about the impacts of COVID-19 on their profitability and business practices. The primary shock was the complete economic closure from the mandated lockdown. The secondary shock was the long-tern cessation of in-person gatherings, including tasting rooms. It is important to note that at the time of this research (12 months after the initial shock), no wineries had closed permanently in the research sites, although there were two wineries that had not yet reopened.

Twelve months after the start of the COVID-19 pandemic, all the wineries reported similar revenue streams to the pre-COVID year. For example, Winery 1 reported revenues up $7 \%$ from the previous year, and Winery 2 stated, "We're probably 40 or $50 \%$ down from the number of people that pass through the store, (but) we have maintained $70 \%$ of our sales, which has stayed pretty steady during COVID". Winery 3 claims their profitability has remained constant during the same time-period, and Winery 5 made up for visitation losses through e-commerce sales. Winery 4 sums up the general attitude, "I am only down about $20 \%$. I'm open $65 \%$ less hours per week. In terms of time off, it's kind of cool, convenient for me".

However, the wineries have had to face changing regulations. Wineries were classified as essential businesses by the state of California during lockdowns, meaning they could remain open to produce, bottle, and sell wine, but could not do tastings. On-farm locations were required to close. Winery 1 , which was the only winery that did not operate an outside tasting room (its tasting room is at the vineyard) explains, "We were allowed to stay open to sell wine out the door, but we weren't able to do the things that we need to be able to do to grow the business. I had to be shut down completely, I don't have a lot of space outdoors." Moreover, the COVID-19 policy changed frequently and without much planning or communication. Winery 3 describes the chaos in the following:

"I think this is the seventh or eighth different rendition of business openings. Then they said, okay, you can taste now. There was blue tape on our counters, we measured off our six feet, we had people spaced out wearing a mask, and taking it off when they sipped their wine. And there was a while in September where we were doing it outside in the parking lot. We could do it outside and not inside. We would roll out the wine barrels, but you can't do that anymore. We've done that back and forth, back and forth".

Most of the wineries used the Paycheck Protection Program (PPP), a federal subsidy to support small businesses. The goal was to help small businesses continue to pay their employees as a means to avoid mass unemployment [47]. Winery 1 used the loans to pay the tasting staff even though they were not working during the lockdown. However, he states:

"The PPP loans were not well-structured for owner-operator businesses, especially farming operations. I get it, this was legislation that was thrown together, but where this really affected guys like me is I'm the primary employee. So, if there's any wages lost, it's primarily mine".

Winery 3 was less able to capitalize on the PPP loans:

"I haven't gotten a large amount. The first PPP, which was pushed, advertised, and promoted to all the businesses, you needed to have great relationships with a banker. They had a big launch and bigger businesses, over 10 employees, got those PPPs. I don't have a lot of loans, so I don't have a banker".

Winery 5 was able to keep employees working on e-commerce sales and did not have to reduce their workforce.

\section{Discussion}

Agriculture is the primary economic activity for many rural communities. Ensuring agricultural sustainability is vital to economic health and supports diversification through other industries, such as tourism. While this research occurred during a period when 
tourism visitation was low, the success of these small businesses can ensure that tourism remains a vital component of the rural economic system, specifically in areas that depend on visitation related to agricultural tourism, post-COVID-19.

The wineries in this study were primarily family-owned, which allowed them to make decisions rapidly and maintain control over cost structures [17]. They were not burdened with a large workforce nor with multiple layers of management. As the pandemic hit, owners were able to pivot quickly to adjust to the regulatory environment. They employed creative solutions, such as curbside pick-up, virtual wine tastings, and a move to e-commerce and social media promotion and sales. All wineries had strong wine clubs which enabled their communication and promotional innovations. These wineries provided little food options, nor were they focused heavily on events or agritourism activities pre-pandemic, so they were not impacted by restrictions on group events or food handling.

Enterprise resilience is defined as the ability for an organisation to survive, adapt, and grow during unforeseen or turbulent change [10]. Evidence suggests that the wineries in this study have adapted well to the COVID-19 pandemic. Direct-to-consumer distribution channels focused on customer relationship-building ensured adequate sales even when direct visitation was impossible. Many of the wineries employed virtual tastings, maintaining a sense of community and providing much-needed relief to customers confined to their homes for months. Direct mail shipments and backdoor sales from the tasting room ensured customers could obtain their favourite varietals, maintaining a sense of loyalty. Resiliency is not necessarily a recovery strategy, but an adaption strategy that can influence the weathering of economic hardship and enhance small businesses during a crisis [12].

The key elements that instill resilience are social capital, training and education, adaptability, knowledge, creativity, receptiveness, and flexibility [13]. The wineries in this study possessed these attributes prior to COVID-19 because of their close ties to customers. For example, while there appears to be limited partnerships between the wineries themselves (Winery 5 is an exception), the social networks with customers appear to be very strong. Many of the wineries in this study had customer emails and phone numbers which allowed for instant communication between the winery and its customers. Customers have historically been used to overcome many challenges, such as harvesting difficulties and limited exposure through grocery or restaurant outlets. All of the winery owners have invested heavily in education, learning the ropes by 'doing'. As hobbyists, personal investment in all aspects of wine-making was part of the lifestyle experience, building flexibility into the business model and allowing for cost-cutting during times of economic shock. Adaptability, creativity, and flexibility was built into the business model prior to the pandemic, as many owners have experimented with a variety of distribution, marketing, and supply chain models. Their small size allowed them to try new things without making a large financial and human resource investment. When ideas have not been fruitful, the business model was quickly adjusted. Creativity is built into the winemaking process, as many view wine as an artisan product. In relation to receptiveness, COVID-19 did not offer much choice, and no one was immune to its impact.

The short management span and family-based decision-making allowed for quick responses to the crisis [10]. The owners had been frontline employees since their inception, which allowed them to maintain keen insights into the needs of their customers, resulting in customer-focused enterprises [32]. The most resilient enterprises remained customerfocused during a crisis [13]. Examples included free shipping to loyal customers and a commitment to not raising prices during the pandemic.

Social capital was also highlighted in the federal financial resources. While not all wineries in this study were able to access the first round of stimulus payments, they were available to those with close banking relationships. While these funds were generally used to support employees, who would otherwise have lost their jobs (federal regulation requires $60 \%$ of PPP loans to be spent on salaries and wages), the owners, who constituted the largest part of the work-force, were not covered. However, it does not appear that 
any of these wineries were in dire positions, as e-commerce sales continued to provide adequate revenue.

\section{Conclusions}

This study has shown that business models established in advance of an economic shock can have lasting impacts on the sustainability of organizations throughout a global catastrophe, such as the COVID-19 pandemic. As governments face bail-out relief for largescale tourism operations (such as cruise lines and corporate-owned hotel and conference facilities), many small-scale, rural wineries have managed to weather the pandemic thus far. While wine production does not appear to have been heavily impacted within this study population, the loss of tourism, specifically through restrictions on tasting rooms and small-scale events, has had an impact. In order for a vibrant tourism industry to return, maintaining the attraction infrastructure, such as local wineries, is required. This research shows that rural wineries in the Sierra Foothills and Russian River regions of California studied here have, thus far, been able to pivot operations and maintain profitability and customer loyalty, primarily due to their business model.

Obvious limitations to this study include the small sample size and the limited regional proximity of the wineries in this study. This is due in part to COVID restrictions in place during data collection. Additionally, the study wineries were all in California, and this study thus has limited geographic scope. The cultural aspects of resiliency and the length and nature of the COVID-19 restrictions may differ in other areas and thus impact results. Future research should attempt to expand on pre-economic shock resiliency and its impact on recovery in other areas of the tourism industry, especially in rural areas dependent on tourism and agriculture. As the tourism industry continues to recover slowly, there appears to be many lessons that can help prepare it for future economic and social global shocks. The sustainability of the modern tourism business model is currently being tested. It is hoped that a more customer-friendly, small-scale approach to rural tourism can be enhanced through this research.

Author Contributions: Equal authorship is given to both authors as this was a joint effort from conceptualization to final editing. Both authors have read and agreed to the published version of the manuscript.

Funding: This research was supported by the Utah Agricultural Experiment Station, Utah State University, and approved as journal paper number 9518.

Institutional Review Board Statement: Not applicable.

Informed Consent Statement: Not applicable.

Data Availability Statement: The data is available on request.

Acknowledgments: We thank the anonymous reviewers of this manuscript and the special issue editors for their helpful comments and suggestions.

Conflicts of Interest: The authors declare no conflict of interest.

\section{References}

1. Ducharme, J. World Health Organization Declares COVID-19 a 'Pandemic'. Here's What That Means. Time Magazine. Available online: https: / time.com/5791661/who-coronavirus-pandemic-declaration/ (accessed on 13 August 2021).

2. Opportunity Insights. Track the Recovery. Available online: http//tracktherecovery.org (accessed on 15 August 2021).

3. Cho, S.; Lee, J.; Winters, J. Lost and Found? Job Loss and Recovery in Rural American during COVID-19. Choices 2021, 36. Available online: https://www.choicesmagazine.org/choices-magazine/theme-articles/rural-development-implications-oneyear-after-COVID-19/lost-and-found-job-loss-and-recovery-in-rural-america-during-COVID-19 (accessed on 14 August 2021).

4. Ajilore, O.; Willingham, Z. Redefining Rural America; Center for American Progress: Washington, DC, USA, 2019.

5. Dobis, E.; Stephens, H.M.; Skidmore, M.; Goetz, S.J. Explaining the spatial variation in American life expectancy. Soc. Sci. Med. 2019, 246, 112759. [CrossRef]

6. Discover California Wines. California Wine Profile 2021. 2021. Available online: https:/ / discovercaliforniawines.com/mediatrade/statistics / (accessed on 14 August 2021). 
7. Krebiehl, A. The Differences between High- and Low-Elevation Wine. Wine Enthusiast. 2021. Available online: https://www. winemag.com/2021/01/05/high-low-elevation-wine-difference/ (accessed on 15 August 2021).

8. Romano, A. How Did 2020's Wildfires Impact California Wine? Wine Spectator. 2021. Available online: https://www. winespectator.com/articles/how-did-2020-s-wildfires-impact-california-wine (accessed on 12 August 2021).

9. Australian Wine Research Institute. Sensory Impact of Smoke Exposure. Available online: https://www.awri.com.au/wpcontent/uploads/2020/02/Sensory-impact-of-smoke-exposure.pdf (accessed on 13 August 2021).

10. Fiksel, J. Sustainability and resilience: Toward a systems approach. Sustain. Sci. Pract. Policy 2006, 2, 14-21. [CrossRef]

11. Carvalho, H.; Duarte, S.; Machado, V. Lean, agile, resilient and green: Divergencies and synergies. Int. J. Lean Six Sigma 2011, 2, 151-179. [CrossRef]

12. Slocum, S.L.; Kline, C. Regional resilience: Opportunities, challenges and policy messages from Western North Carolina. Anatolia Int. J. Tour. Hosp. Res. 2014, 25, 403-416. [CrossRef]

13. Ahmed, R.; Seedat, M.; van Niekerk, A.; Bulbulia, S. Discerning Community Resilience in Disadvantaged Communities in the Context of Violence and Injury Prevention. S. Afr. J. Psychol. 2004, 34, 386-408. [CrossRef]

14. Seville, E.; Van Opstal, D.; Vargo, J. A Primer in Resiliency: Seven Principles for Managing the Unexpected. Glob. Bus. Organ. Excel. 2015, 34, 6-18. [CrossRef]

15. Sabatino, M. Economic crisis and resilience: Resilient capacity and competitiveness of the enterprises. J. Bus. Res. 2016, 69, 1924-1927. [CrossRef]

16. Christopher, M.; Towill, D.R. Supply Chain Migration from Lean and Functional to Agile and Customised. Supply Chain. Manag. Int. J. 2000, 5, 206-213.

17. Mzid, I.; Kahachlouf, N.; Soparnot, R. How does family capital influence the resilience of family firms? J. Int. Entrep. 2019, 17, 249-277. [CrossRef]

18. Chrisman, J.J.; Chua, J.H.; Steier, L.P. Resilience of Family Firms: An Introduction. Entrep. Theory Pract. 2011, 35, 1107-1119. [CrossRef]

19. Sirmon, D.G.; Hitt, M.A. Managing resources: Linking unique resources, management, and wealth creation in family firms. Entrep. Theory Pract. 2003, 27, 339-358. [CrossRef]

20. Haynes, G.W.; Danes, S.M.; Stafford, K. Influence of federal disaster assistance on family business survival and success. J. Conting. Cris. Manag. 2011, 19, 86-98. [CrossRef]

21. Calgaro, E.; Lloyd, K. Sun, sea, sand and tsunami: Examining disaster vulnerability in the tourism community of Khao Lak, Thailand. Singap. J. Trop. Geogr. 2008, 29, 288-306. [CrossRef]

22. Davis, J.P.; Eisenhardt, K.M.; Bingham, C.B. Optimal Structure, Market Dynamism, and the Strategy of Simple Rules. Adm. Sci. Q. 2009, 54, 413-452. [CrossRef]

23. Engeset, A. "For better or for worse"-The role of family ownership in the resilience of rural hospitality firms. Scand. J. Hosp. Tour. 2020, 20, 68-84. [CrossRef]

24. Pham, D.; Pham, P.; Thomas, A. Integrated production machines and systems-Beyond lean manufacturing. J. Manuf. Technol. Manag. 2008, 19, 695-711. [CrossRef]

25. Thomas, A.; Pham, D.T.; Francis, M.; Fisher, R. Creating resilient and sustainable manufacturing businesses-A conceptual fitness model. Int. J. Prod. Res. 2014, 53, 3934-3946. [CrossRef]

26. Prahalad, C.K.; Hamel, G. The core competence of the corporation. Harv. Bus. Rev. 1990, 68, 79-91.

27. Thomas, R.; Shaw, G.; Page, S.J. Understanding small firms in tourism: A perspective on research trends and challenges. Tour. Manag. 2011, 32, 963-976. [CrossRef]

28. Thomas, A.; Byard, P.; Francis, M.; Fisher, R.; White, G.R. Profiling the resiliency and sustainability of UK manufacturing companies. J. Manuf. Technol. Manag. 2016, 27, 82-99. [CrossRef]

29. Peterson, G. Political ecology and ecological resilience:: An integration of human and ecological dynamics. Ecol. Econ. 2000, 35, 323-336. [CrossRef]

30. Khan, O.; Christopher, M.; Creazza, A. Aligning product design with the supply chain: A case study. Supply Chain Manag. Int. J. 2012, 17, 323-336. [CrossRef]

31. Christopher, M. The Agile Supply Chain: Competing in Volatile Markets. Ind. Mark. Manag. 2000, 29, 37-44. [CrossRef]

32. Ross, B. Ten tips to winning at consumer centricity: For retailers and manufacturers. J. Consum. Mark. 2009, 26, 450-454. [CrossRef]

33. Ismail, H.S.; Poolton, J.; Sharifi, H. The role of agile strategic capabilities in achieving resilience in manufacturing-based small companies. Int. J. Prod. Res. 2011, 49, 5469-5487. [CrossRef]

34. Gebauer, H.; Gustafsson, A.; Witell, L. Competitive advantage through service differentiation by manufacturing companies. J. Bus. Res. 2011, 64, 1270-1280. [CrossRef]

35. Burt, R.S. Structural Holes; Cambridge University Press: Cambridge, UK, 1992.

36. Dyer, W.G.; Nenque, E.; Hill, J. Toward a theory of family capital and entrepreneurship: Antecedents and outcomes. J. Small Bus. Manag. 2014, 52, 266-285. [CrossRef]

37. Nahapiet, J.; Ghoshal, S. Social capital, intellectual capital, and the organizational advantage. Acad. Manag. Rev. 1998, 23, 242-266. [CrossRef] 
38. Miller, D.; Wright, M.; Le Breton-Miller, I.; Scholes, L. Resources and Innovation in Family Businesses: The Janus-Face of Socioemotional Preferences. Calif. Manag. Rev. 2015, 58, 20-40. [CrossRef]

39. Maroudas, L.; Kyriakaki, A.; Gouvis, D. A community approach to mountain adventure tourism development. Anatolia Int. J. Tour. Hosp. Res. 2004, 15, 5-18. [CrossRef]

40. Corbin, J.; Strauss, A. Basics of Qualitative Research: Techniques and Procedures for Developing Grounded Theory, 4th ed.; Sage Publications: Thousand Oaks, CA, USA, 2014.

41. Richards, L.; Morse, J. User's Guide to Qualitative Methods, 2nd ed.; Sage: London, UK, 2007.

42. Small Business Act. As Amended Through P.L. 117-6; 1958; Enacted 30 March 2021. Available online: https://www.govinfo.gov/ content/pkg/COMPS-1834/pdf/COMPS-1834.pdf (accessed on 13 August 2021).

43. Ateljevic, I.; Doorne, S. 'Staying Within the Fence': Lifestyle Entrepreneurship in Tourism. J. Sustain. Tour. 2000, 8, 378-392. [CrossRef]

44. Howkins, J. The Creative Economy: How People Make Money from Ideas; Penguin: London, UK, 2002.

45. Slocum, S.L.; Curtis, K. Farm diversification through farm shop entrepreneurship in the UK. J. Food Distrib. Res. 2017, 48, 35-51.

46. Yoon, Y.; Uysal, M. An examination of the effects of motivation and satisfaction destination loyalty: A structural model. Tour. Manag. 2005, 26, 45-56. [CrossRef]

47. United States Treasury Department. Coronavirus Aid, Relief, and Economic Security Act. COVID-19 Economic Relief. 2020. Available online: https:/ / home.treasury.gov/policy-issues/coronavirus (accessed on 12 August 2021). 